УДК: 316.422.42

DOI: https://doi.org/10.32689/2617-

2224-2019-18-3-227-239

Конотопець Свгенія Олегівна, студентка 3-го курсу кафедри соиіологіi та політології, Національний авіаційний університет, 03058, м. Київ, просп. Космонавта Комарова, 1, тел.: +38 (098) 58387 65,e-mail:eok.eok37@gmail.com

ORCID: 0000-0002-5529-3811

Конотопеи Евгения Олеговна, студентка 3-го курса кафедры социологии и политологии, Национальный авиаиионный университет, 03058, г. Киев, просп. Космонавта Комарова, 1, тел.: +38 (098) 58387 65, e-mail:eok.eok37@ gmail.com

ORCID: 0000-0002-5529-3811

Konotopets Yevghenia Olegivna, student of the 3 course of the Department of Political Science and Sociology, National Aviation University, 03058, Kyiv, Prosp. Kosmonavta Komarova, 1, tel.: +38 (098) 58387 65,e-mail:eok.eok37@gmail.com

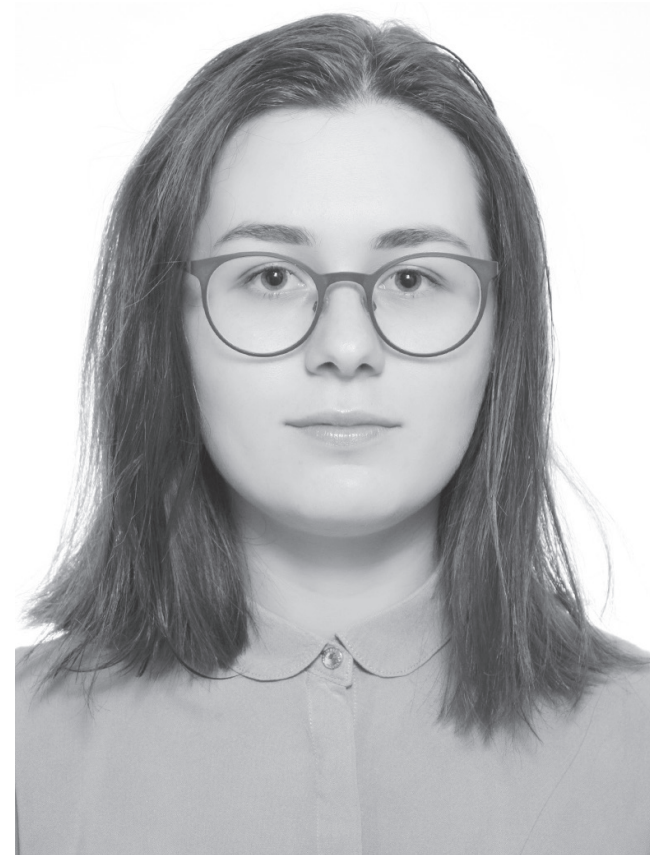

ORCID: 0000-0002-5529-3811

\title{
СТРАТЕГІЇ СТАЛОГО РОЗВИТКУ В УМОВАХ ЦИВІЛІЗАЦІЙНИХ ЗРУШЕНЬ: КЕЙС СУЧАСНОЇ УКРАЇНИ (АРХЕТИПНИЙ ПІДХІД)
}

Анотація. Сучасний світ невпинно розвивається. Прогрес у всіх сферах людського життя досяг небаченої раніше швидкості. Наприклад, ринок техніки та технологій повністю оновлюється за 5 років. Для підтримання такого рівня прогресу глобальне суспільство створює різноманітні концепції і стратегії. Саме вони є орієнтиром для кожного, хто бажає ефективно розвиватися. Концепція сталого розвитку наразі є провідною для більшості країн світу. Саме вона визначає напрями подальшого розвитку держав, їх політику на міжнародній та внутрішній арені, закони, які вони приймають, тощо. Вкорінена ця концепція не лише на державному рівні, нею керуються й організації при плануванні своєї діяльності, а також звичайні люди у своєму повсякденному житті. Метою статті є розгляд особливостей стану українського суспільства та вироблення нової стратегії сталого розвитку для України. У процесі аналізу українського суспільства використовувалися теорії класиків соціологічної та психологічної думки: Т. Парсонса, О. Шпенглера, 
П. Штомпки, К. Юнга. За їх допомогою було проаналізовано українську суспільну сучасність та виявлено теоретичне підтвердження можливості успішного розвитку країни. Також було встановлено відповідність законодавства України до цілей сталого розвитку. Це дало можливість отримати реальну картину дійсності українців та запропонувати можливу стратегію сталого розвитку країни, стратегію культурного розвитку, яка дасть можливість суспільству якісніше дотримуватися визначених цілей та прогресувати в сучасному “світі змін”. Більш глибоке вивчення проблеми дало змогу на прикладі діяльності та державної політики таких держав, як Америка, Південна Корея, Казахстан показати доцільність запровадження запропонованої стратегій. У ході роботи було сформовано пропозиції щодо подальшої діяльності країни згідно зі стратегією культурних змін.

Ключові слова: сталий розвиток, соціальні зміни, реформа, суспільний розвиток, прогрес, культура, українці, архетип, архетип Дитини.

\section{СТРАТЕГИИ УСТОЙЧИВОГО РАЗВИТИЯ В УСЛОВИЯХ ЦИВИЛИЗАЦИОННЫХ СДВИГОВ: КЕЙС СОВРЕМЕННОЙ УКРАИНЫ (АРХЕТИПИЧЕСКИЙ ПОДХОД)}

Аннотация. Современный мир постоянно развивается. Прогресс во всех сферах человеческой жизни достиг невиданной ранее скорости. Например, рынок техники и технологий полностью обновляется за 5 лет. Для поддержания такого уровня прогресса глобальное общество создает различные концепции и стратегии. Именно они являются ориентиром для каждого, кто желает эффективно развиваться. Концепция устойчивого развития сейчас ведущая для большинства стран мира. Именно она определяет направления дальнейшего развития государств, их политику на международной и внутренней арене, законы, которые они принимают и т. п. Укоренена эта концепция не только на государственном уровне, ею руководствуются и организации при планировании своей деятельности, а также обычные люди в своей повседневной жизни. Целью статьи является рассмотрение особенностей состояния украинского общества и выработка новой стратегии устойчивого развития для Украины. При анализе украинского общества использовались теории классиков социологической и психологической мысли: Т. Парсонса, О. Шпенглера, П. Штомпки, К. Юнга. С их помощью была проанализирована украинская общественая современность и выявлены теоретические подтверждения возможности успешного развития страны. Также было установлено соответствие законодательства Украины с целями устойчивого развития. Это позволило получить реальную картину действительности украинцев и предложить возможную стратегию устойчивого развития страны, стратегию культурного развития, которая позволит обществу качественнее соблюдать определенные цели и прогрессировать в современном “мире изменений”. Более глубокое изучение проблемы дало возможность на примере государственной политики таких стран, как Америка, Южная Корея, Казахстан показать целесообразность введения предложенной стратегии. В 
ходе работы были сформированы предложения по дальнейшей деятельности страны согласно стратегии культурных изменений.

Ключевые слова: устойчивое развитие, социальные изменения, реформа, общественное развитие, прогресс, культура, украинцы, архетип, архетип Ребенка.

\title{
STRATEGIES FOR SUSTAINABLE DEVELOPMENT IN CONDITIONS OF CIVILIZATIONAL DEFECTS: KAYS OF MODERN UKRAINE (ARCHITECTURE APPROACH)
}

\begin{abstract}
The modern world is constantly evolving. Progress in all spheres
\end{abstract} of human life has reached unprecedented speed. For example, the technology market is completely upgraded for 5 years. Global society creates a variety of concepts and strategies in order to maintain such a level of progress. They are the benchmark for anyone who wants to grow effectively. The Concept of Sustainable Development is the leading way for most of the countries. It determines the directions for the development of the countries, their policies on the international and domestic scenes, the laws that they adopt, etc. This concept rooted not only at the state level. Organizations are guided by it when they plan their own activities. Also, ordinary people are guided by it in their everyday lives. The purpose of the article is to review the peculiarities of the state of Ukrainian society and the development of a new strategy for sustainable development of Ukraine. In the analysis theories of classics of sociological and psychological thought were used: T. Parsons, O. Spengler, P. Stompky, K. Jung. With their help, the Ukrainian social modernity was analyzed and the theoretical confirmation of the possibility of successful development of the country was discovered. The compliance of Ukraine's legislation with sustainable development goals was also established. This allowed us to get a real picture of the reality of Ukrainians and to propose a possible strategy for sustainable development of the country, a strategy of cultural development that would allow the society to achieve the goals better and to make progress in the modern "world of changes". A deeper immersion allowed (on the example of the activities and state policies of such states as America, South Korea, and Kazakhstan) to demonstrate the feasibility of introducing the proposed strategy. During the course of the work, proposals were made for further activities of the country in accordance with the strategy of cultural changes.

Keywords: sustainable development, social changes, reform, social development, progress, culture, Ukrainians, archetype, Child archetype.

Постановка проблеми. У 1992 р. в Ріо-де-Жанейро на міжнародній конфереції в рамках прийняття "Порядку денного на XXI століття" було проголошено парадигмальний напрям розвитку людства - забезпечення сталого розвитку. “Сталий розвиток” є триєдиною концепцією економічного, екологічного та соціального розвитку, що, водночас, дає 
змогу забезпечити належне існування як для сучасних, так і майбутніх поколінь. Україна як одна з європейських країн, що орієнтована на прогресивне зростання, також намагається будувати свою політику згідно з тезами сталого розвитку. На жаль, за 27 років незалежності прогрес зазначеного напряму відбувається дуже повільно. В Україні не існує загальноприйнятої стратегії впровадження концепції сталого розвитку, яка б враховувала реалії та особливості економічної, екологічної та соціальної сфер українського суспільства.

\section{Аналіз останніх публікацій.} Концепція сталого розвитку впроваджується на глобальному рівні. Для її розвитку та розробки моделей впровадження залучені вчені з усіх країн. Вагомий внесок у розробку концепції сталого розвитку зробили: В. М. Андерсон, Н. М. Андрєєва, В. В. Беренс, 3. В. Герасимчук, Р. В. Кейтс, Д. Л. Медоуз, Д. Х. Медоуз, Й. Рэндерс, М. А. Хвесик та ін. $\mathrm{У}$ роботі ми звернемо увагу на праці таких вітчизняних науковців, як I. К. Бистряков, О. I. Бородіна, С. М. Ілляшенко, М. А. Хвесик та проаналізуємо їх підходи до впровадження концепції сталого розвитку в Україні.

Мета статті. Проаналізувати процес впровадження сталого розвитку в Україні за допомогою класичних соціологічних теорій та запропонувати стратегію розвитку українського суспільства на основі ідеї сталого розвитку.

Виклад основного матеріалу дослідження. Прогрес є метою життєдіяльності будь-якого суспільства.
Кожна цивілізація, кожен народ, кожна людина намагаються обгрунтувати свою впевненість у кращому майбутньому. Українці не є виключенням. Україна є відносно молодою державою. Але етнологічне коріння українців можна простежити на віки в історії. Український народ сильний і самобутній, однак він завжди розглядався як частина слов'ян. Тому теоретичні обгрунтування майбутнього розвитку українців ми знаходимо, насамперед, у вчених, які поглиблювали теорії розвитку цивілізацій М. Я. Данилевського і О. Шпенглера.

М. Я. Данилевський вважав, що не існує загальнолюдської цивілізаціï, існують різні культурно-історичні типи цивілізацій. О. Шпенглер був послідовником його ідей. Кожен з цих вчених у своїх теоріях зосереджував увагу на слов'янській цивілізації, точніше на зародженні слов'янської культури, що є першим етапом у розвитку культурно-історичних типів цивілізацій. За логікою О. Шпенглера, слов'янська культура стоїть тільки на початку свого “життєвого циклу” і ще має пройти три фази: 1) докультурний, або "етнографічний” стан; 2) власне культурний період, що підрозділяється на "ранній" і “пізній” періоди; 3) період цивілізації. Тобто саме зараз, у XXI ст., слов’яни мають шанси на успішний розвиток своїх суспільств.

Оскільки українці завжди були частиною слов'ян, тезу про початок розвитку можна застосувати i до українського суспільства. Однак сповна реалізувати свою пасіонарність, на нашу думку, українське суспільство зможе, зокрема, якщо впроваджуватиме універсальний тренд 
глобального світу - ідеї стабільного розвитку (через розбудову державної політики та формування культурних, поведінкових цінностей на ïх основі). Адже, на нашу думку, саме ця концепція є найбільш відповідною безпековим викликам сучасного глобального світу, є концептуально обгрунтованою та результативно впроваджується у багатьох країнах світу. Ця концепція гарантує прогресивний розвиток на основі поступових соціальних змін (зокрема, через соціальні реформи як вид соціального прогресу) [1].

Також для підтвердження можливості успішного розвитку України ми звернимося до концепції архетипів К. Юнга. Ми вважаємо залучення цієї концепції доречним, адже саме універсальне психічне лежить в основі всіх суспільних структур. Архетипи - це соціальні інстинкти [2], які виступають в якості структурних елементів колективного несвідомого. Їх специфіка стосується людства як певного цілого [2]. К. Юнг виділяв кілька архетипів колективного несвідомого: Матері, Дитя, Тіні, Анімуса, Аніми, Мудрого старця, Мудрої старої. Застосовуючи цю концепцію до українців як великого об'єднання людей, можна зауважити, що їм притаманний архетип Дитини. Як у великої соціальної групи, в українців можна спостерігати жагу до нового та любов до навчання. Тож при належній освітній діяльності державного апарату та утверджені описаної вище концепції сталого розвитку, суспільство має шанси на стабільне прогресивне зростання. Навіть сам К. Юнг зауважував, що дитина - потенційне май- бутне, і суттєвими аспектами мотивів дитини є майбуття [3].

Підхід сталого розвитку було проголошено на конференції 1992 р. і мав він таке формулювання: "розвиток, який задовольняє потреби нинішнього покоління без шкоди для можливості майбутніх поколінь задовольняти свої власні потреби". Наразі це є основним трактуванням концепції сталого розвитку, на якому базуються усі існуючі стратегії сталого розвитку.

Стратегію можна визначити і як певний парадигмальний вектор, в контексті якого розглядається процес становлення сталого розвитку. Наразі існує досить багато різних парадигмальних теорій. Наприклад, підходи випереджувального розвитку, стратегія поступових соціальних змін (Дж. Дак) та ін. Різні підходи визначають, яким чином той чи інший суб’єкт вважає за потрібне кординувати існуючий розвиток країни, регіонів, субрегіонів тощо із сталим розвитком, основні цілі якого сформовано у документах ООН [4]. Сталий розвиток передбачає гармонійний розвиток трьох сфер: екологічної (для збереження довкілля), економічної (для забезпечення зростання за умови збереження соціальної справедливості та екологічної відповідальності), соціальної (для впровадження та підтримки справедливого розподілу благ) [5]. I саме стратегія гармонійно координуе послідовність змін у сучасному суспільстві. Адже зрозуміло, що економічна, екологічна, соціальна сфери мають як спільні вектори розвитку, так і діаметрально протилежні, що потребують узгодження. 
В Україні наразі немає чіткої стратегії впровадження принципів сталого розвитку. Діяльність у цьому напрямі фрагментарна та нерезультативна. 3 основних документів України щодо сталого розвитку можна визначити Указ Президента України “Про Стратегію сталого розвитку "Україна - 2020" [6] та Національну доповідь “Цілі сталого розвитку: Україна” [7]. Виходячи 3 вказаних документів, зазначаємо, що Україна дотримується таких векторів: розвитку, безпеки, відповідальності, гідності. У рамках цих векторів передбачається реалізація 62-х реформ та програм розвитку держави. Хоча ці вектори мають взаємодоповнювати одне одного, очевидно, що виконання всіх завдань одночасно в умовах політико-економічної нестабільності в сучасній Україні призводить до загального гальмування прогресу.

Щодо формування культурних цінностей ситуація в Україні зовсім не контролюється. Для прикладу розглянемо екологічне виховання українців. У 2017 р. було прийнято "Національну стратегію управління відходами в Україні до 2030 року”, а в 2018 р. - Закон про "Стратегічну екологічну оцінку”. На рівні громадян метою законів було сприяння сталому розвитку шляхом охорони довкілля та безпеки життєдіяльності людей. На жаль, ніякої системної (на рівні держави) інформаційної чи освітньої кампаній не проводилося. Тож більшість громадян України не мають знань та навичок щодо впровадження нових підходів поводження із сміттям, енергоефективності, екологічно відповідальної підприємницької діяльності тощо.
Сучасний стан розвитку суспільства, як ніколи, є відображенням часових змін у ньому. Час є універсальним контекстом соціального життя. Але при цьому час є не тільки універсальним виміром соціальних зміни, але і їх основою, конструюючим чинником [1]. Теперішній історичний момент в Україні відчувається як ніколи гостро. Вперше з моменту проголошення незалежності України українці починають відчувати зміни. Революція гідності, анексія АРК, воєнні дії на території країни - усе це $є$ виявами трансформації суспільства. Відчуваючи ці зміни, українці починають згуртовуватися для забезпечення своєї безпеки і безпеки своєї країни. Це засвідчує зростання рівня патріотичних настроїв українців [8].

На жаль, бажання діяти є не єдиною умовою успішного розвитку. Наразі можна констатувати, що українці готові до змін, але вони не мають теоретичного та культурного бекграундів для згуртованих, обдуманих дій. Сьогодні поступово змінюється увесь світ. Цілі сталого розвитку крок за кроком виконуються компаніями та громадянами різних країн. Наприклад, транснаціональна компанія Adidas випустила модель кросівок UltraBoost Uncaged Parley вироблених із океанічного сміття. Широковідомий будинок моди Chanel відмовився від використання шкіри та хутра. А нещодавно по всьому світі відбулася масова акція школярів із закликом захистити планету від екологічної загрози. Почалася вона із звичайної шведської школярки Грети Тунберг, яка у серпні 2018 р. кожної п’ятниці виходила на страйк заради клімату під будівлею парламенту 
Швеції. Наразі теги \#Fridays4future i \#Climatestrike швидко розповсюджуються. Багато студентів і дорослих почали протестувати по всьому світу.

Останнім часом жителі України зменшили використання газу вдвічі. Звісно можна намагатися пояснити це екологічною свідомістю українців, але, насправді, це всього лише вимушена необхідність викликана економічною ситуацією в державі. На жаль, в українському суспільстві екологічно відповідальні установки як феномен буденної свідомості формуються дуже повільно. Сьогодні час “стискається" з неймовірною швидкістю. I хоча українці вже відчули необхідність змін, вони до них все ще залишаються не готовими.

Для оптимізації роботи держави та суспільства в Україні необхідно зазначити, які саме критерії для впровадження сталого розвитку слід використовувати. Проаналізувавши реформи, що відбуваються, ми робимо висновок, що майже всі вони передбачають зміни інституційного характеру, тобто, структурні зміни. Саме тут необхідно звернутися до класика структурно-функціонального підходу в соціології - Т. Парсонса.

T. Парсонс наголошує, що соціальна система має власну структуру із рівнями: індивід - група - інститути - суспільство загалом. Очевидним фактом є те, що зміни однієї із складових зумовлюють хоча б мінімальні зміни в інших. Отже, інституціональні зміни українського суспільства мають бути підкріплені змінами і в інших сферах. Зауважимо, інституційні зміни продиктовані новообраним вектором європейського розвит- ку (тобто змін на рівні суспільства). Але ми не знаходимо жодного нормативно-правового документа на підтримку перетворень на індивідуальному чи груповому рівнях. В Указі Президента України "Про Стратегію сталого розвитку “Україна - 2020" зазначено, що в Україні створено нову ідею - "ідею гідності, свободи і майбутнього” [6]. Але не має належних інших документів, які б декларували, наприклад, цілеспрямоване намагання формувати нові ціннісні установки українців у напрямі підвищення екологічно відповідальної поведінки. А саме культурний розвиток є одним з визначальних факторів успішності соціальних реформ, зокрема i формування нових інституцій у суспільстві.

Все ж необхідно повернутися до критеріїв, що допоможуть встановити концепцію сталого розвитку як одну з провідних концепцій розбудови суспільства. Вважаємо доцільним знов таки звернутися до Т. Парсонса. У своїй роботі “Про структуру соціальної дії” він пише: “для забезпечення стабільності всієї соціальної системи життєво важливим є наявність згоди по відношенню до ... основних орієнтацій вибору з альтернатив" [9]. Тобто більшість людей, які є членами суспільства, мають схвалювати та приймати однакові рішення для стабільної та прогресивної діяльності системи. Найефективнішим способом розвитку одностайності в прийнятті рішень є розвиток спільних критеріїв прийняття рішень, тобто цінностей і моралі людей, розвиток їх культури.

Підтвердження першочерговості культури в розвитку суспільства 
можна знайти і у О. Шпенглера. Він розглядає світову культуру як низку незалежних одна від одної культур, що проживають, подібно до живих організмів, періоди зародження, становлення і вмирання [10].

Таку саму необхідність розвитку культури як на загальному, так й індивідуальному рівнях можна вивести і з концепції архетипів К. Юнга. Адже для активізації архетипу необхідна “психічна енергія", напруження між примітивною природою новонародженого і його високодиференційованою спадковістю [2]. Поряд з досвідом, залишеним предками, наразі українці потребують якомога швидшого формування нових сучасних культурних звичок на основі цього досвіду.

На нашу думку, формування нової ціннісної картини світу в українців сприятиме впровадженню ідей сталого розвитку на практиці, в тому числі й iї розвитку у буденній свідомості та поведінці кожної людини. Також важливим наслідком переоцінки ціннісних орієнтацій українців має стати розбудова громадянського суспільства, що є одним з гарантів сталого розвитку в документі “Україна - 2020".

Важливим фактом $є$ те, що хоча концепція сталого розвитку передбачає моніторинг людського розвитку, система не включає моніторинг цінностей і культури людей (контролюються такі показники): 1) рівень життя (оцінений через ВНП на душу населення); 2) рівень грамотності населення (очікувана тривалість навчання); 3) очікувана тривалість життя (оцінка довголіття). Це означає, що необхідно окремо зосередити увагу на розвитку культурних установок українців, що відповідатиме цілям сталого розвитку.

Багато держав наразі намагаються розвивати культурну сферу суспільства для популяризації певних ціннісних орієнтацій. Насамперед це відбувається за допомогою масової культури. У Великому енциклопедичному словнику масову культуру пояснюють як “поняття, що охоплює різноманітні і різнорідні явища культури XX ст., які поширені в зв'язку з науково-технічною революцією і постійним оновленням засобів масової комунікаціі” [11].

Головним розповсюджувачем масової культури є США. Американський кінематограф є наймасовішим у світі. "РКО", "Парамаунт", "Коламбія", "Метро-Голдвін-Майер”, "20 $0^{\text {th }}$ Century Fox" - всі ці компанії $є$ виробниками фільмів, мультиків та телепередач, які транслюють американські цінності. Прихильників американського кінематографу можна знайти скрізь, а відтак і прихильників американських цінностей. Та сама ситуація склалася і з музичною сферою США. Американські співаки та актори є чи не найпопулярнішими людьми на Землі. Мільйони наслідують їх спосіб життя та поділяють їх думки.

Хоча американський ноумен масової культури є найрозповсюдженішим, варто звернути увагу ще на декілька прикладів із сучасності. Зараз набирають популярності виконавці із Південної Кореї. Однією з найпопулярніших груп є BTS. Нещодавно учасники цієї групи брали участь у 73 Генеральній Асамблеї ООН, де проголошували промову. BTS разом із ЮНІСЕФ є засновниками кампа- 
нiї Love Myself, яка покликана підтримувати молодих людей по всьому світу. Починаючи з листопада 2017 р. більше ніж 500 млн корейських вон було пожертвувано на підтримку цієї кампанії самими співаками. Наразі Південна Корея відома тим, що різні організації дуже активно працюють над поліпшенням якості життя дітей та підлітків у всьому світі.

Також цікавим є розвиток культури Казахстану. Казахстанська музична культура не є настільки ж популярною. Вона переважно орієнтована на внутрішній ринок споживачів. Але в рамках своєї країни вона має неабиякий вплив. Ninety One найпопулярніший бойз-бенд, який є зачинателем молодіжної моди в Казахстані. Примітним є факт, що один з учасників гурту Дулат Мухаметкалієв є “народним депутатом" з 2018 р. Це стало можливим через референдум, за допомогою якого молодого артиста і було призначено на посаду.

Вплив культури на свідомість людей значний. Цей факт не можна заперечувати. Українці потребують швидкої та кардинальної зміни свідомості для того, щоб зуміти пристосуватися до змін у світі, що зараз відбуваються. На нашу думку, для переорієнтації ціннісної картини українців та впровадження стратегії культурного розвитку, по-перше, слід взяти за взірець цінності громадян Європейського Союзу, які зазначені у Маастріхтському договорі: “Союз заснований на цінностях поваги людської гідності, свободи, демократії, рівності, правової держави $і$ дотримання прав людини, включаючи права осіб, що належать до меншин. Ці цінності є спільними для держав-членів в рамках суспільства, що характеризується плюралізмом, недискримінацією, терпимістю, справедливістю, солідарністю і рівністю жінок і чоловіків" [12]. По-друге, необхідно почати активне формування цих цінностей у нових поколінь через викладання у школі відповідних дисциплін, створення клубів та спілок 3 метою поширення ідеї сталого розвитку та його культури, публікації необхідних матеріалів у 3MI, Інтернеті. По-третє, необхідно розвивати масову українську культуру, що стане транслятором нових українських цінностей та напрямів зростання в руслі концепції сталого розвитку.

\section{Висновки і перспективи подаль-} ших досліджень. Сьогодні концепція сталого розвитку є провідною у більшості країн світу. На жаль, ситуація в Україні дещо інша. Ні де-юре, ні де-факто в країні не проголошено домінування принципу сталого розвитку у комплексних програмах розбудови держави та суспільства. I якщо прийняття відповідних офіційних документів може відбутися без перешкод, реальне впровадження принципу сталого розвитку серед людей гальмується їх ціннісно-моральними орієнтаціями, які не повною мірою відповідають викликам сучасного суспільства. Яскравим прикладом є "Національна стратегія управління відходами в Україні до 2030 року”. Вона є офіційним документом України і декларує поодинокі інституційні зміни, але вона не супроводжується жодними освітніми чи інформаційними кампаніями. Через це нові цінності екологічно-відповідальної поведінки українців як установки масової свідомості не формуються. 
Отже, необхідна державна підтримка формування і розвитку в українців нових цінностей та культурних установок відповідно наративам сталого розвитку - екологічної відповідальності, соціальної справедливості, неспоживацької поведінки тощо. Найбільш дієвий спосіб досягнути цього - через освітні та інформаційні кампанії. Їх дієвість в українському суспільстві обгрунтовується властивим йому значною мірою архетипом Дитини, завжди відкритої до навчання та пізнання нового. Поступовість і системність підтримки означених перетворень у свідомості українців, популяризація важливості об'єднання зусиль суспільства в контексті сучасних безпекових викликів посилюватиме інституційні зміни, пов'язані з реформами у секторах, дотичних до впровадження ідей сталого розвитку в економіку, охорону навколишнього середовища, соціальну сферу. Наразі реформи, що відбуваються в Україні, потребують додаткового вивчення 3 метою їх трансформування для більшої відповідності концепції сталого розвитку, підкріплення освітніми та інформаційно-просвітницькими кампаніями, які, хоча і потребують багато часу, демонструють високу результативність у довготерміновій перспективі.

\section{СПИСОК ВИКОРИСТАНИХ ДЖЕРЕЛ}

1. Штомпка П. Социология социальных изменений / пер. с англ. под ред. В. А. Ядова. - М.: Аспект Пресс, 1996. - 416 с. - (Программа "Высшее образование").

2. Донченко О. Архетипи - спільне в нашому житті (розпізнавання ар- хетипів як шлях до унікальності) / Олена Донченко // Психологія особистості. - 2011. - С. 170-181.

3. Юнг К. Психология архетипа ребенка [Электронный ресурс] / Карл Юнг. - Режим доступа: https:// bookap.info/book/yung_psihologiya arhetipa_rebenka/

4. Большунова А. I. Основні концепції сталого розвитку [Текст] / А. І. Большунова // Екологічний менеджмент у загальній системі управління : тези доповідей Десятої щорічної Всеукраїнської наук. конф., (Суми, 20-21 квітня 2010 р.) / відп. за вип. О. М. Теліженко. - Суми : СумДУ, 2010. - Ч. 1. - C. 23-25.

5. Буринська О. I. Еволюція концепції сталого розвитку як головної парадигми нового тисячоліття [Текст] / О. I. Буринська // Наук. вісн. Ужгород. нац. ун-ту : Серія: Міжнародні економічні відносини та світове господарство / голов. ред. М. М. Палінчак. - Ужгород : ВД “Гельветика”, 2016. - Вип. 7. - Ч. 1. - С. 57 60.

6. Про Стратегію сталого розвитку "Україна - 2020" [Електронний ресурс] // Президент України. - 2015. Режим доступу: https://zakon1.rada. gov.ua/laws/show/5/2015\#n10

7. Sustainable Development Goals: Ukraine, 2017. - 168 c. - (MINISTRY OF ECONOMIC DEVELOPMENT AND TRADE OF UKRAINE).

8. Патріотичні настрої українці [Електронний ресурс]. - 2017. - Режим доступу: http://ratinggroup. ua/files/ratinggroup/reg_files/rg_ patriotyzm_082017.pdf

9. Парсонс T. О структуре социального действия. - М.: Академ. проект, 2000. $-880 \mathrm{c}$.

10. Шиенглер О. Закат Европы: Очерки морфологии мировой истории. T. 1. Образ и действительность. Минск, 1998. 
11. Большой Энциклопедический словарь [Электронный ресурс]. - Peжим доступа: https://dic.academic. $\mathrm{ru} /$ contents.nsf/enc3p/

12. Договір про Європейський Союз [Електронний ресурс] // Свропейський Союз. - 1992. - Режим доступу: http://zakon.rada.gov.ua/laws/ show /994_029

13. Стратегія сталого розвитку України до 2030 року, 2017. - 112 с.

14. Гаращук О. В. Освітнь--наукова парадигма сталого розвитку продуктивник сил України / О. В. Гаращук, B. I. Куценко // Проблеми і перспективи економіки та управління / О. В. Гаращук, В. І. Куценко, 2016. № 3 (7). - С. 135-141.

15. Донченко О. А. Архетипи соціального життя i політика: Глибинні регулятиви психополітичного повсякдення / О.А.Донченко, Ю. В. Романенко. - К. : Либідь, 2001. - 334 c.

16. Ілляменко С. М. Підходи до вибору перспективних напрямів інноваційно-орієнтованого сталого розвитку України / С. М. Ілляшенко // Сталий розвиток - XXI століття: управління, технології, моделі. Дискусії 2015: колективна монографія / [В. В. Акулов-Муратов, О. Н. Алимов, В. М. Андерсон, Н. М. Андрєєва та ін.] / НАН України, ДУ “Ін-т економіки природокористування та сталого розвитку НАН України”, НТУ "Київський політехнічний ін-т”, Ін-т телекомунікацій та глобального економічного простору НАН України, Ін-т економіко-правових досліджень НАН України, Вища економіко-гуманітарна школа, Міжнар. асоціація сталого розвитку : за наук ред. проф. С. В. Хлобистова. - Черкаси: Видавець Чабаненко Ю. А., 2015. - С. 33-40.

17. Хвесик M. А. Інноваційні домінанти сталого розвитку Укра- їни [Електронний ресурс] М. А. Хвесик, I. К. Бистряков // Проблеми інноваційно-інвестиційного розвитку. Серія : Економіка та менеджмент. - 2016. - № 9. C. 182-193. - Режим доступу: http:// nbuv.gov.ua/UJRN/Piir_2016_9_23

18. Архимандрит Георгий (Шестун). О жизни и учении великого русского мыслителя ... [Электронный ресурс] / Архимандрит Георгий (Шестун) // Русская народная линия. 2012. - Режим доступа: http:// ruskline.ru/analitika/2012/06/16/ n i k o l a j_ y a k o v l e vi c h_ danilevskij_18221886/

19. Шегута $\bar{M}$. А. Славянская цивилизация: история и современные реалии [Электронный ресурс] / M. А. Шегута. - Режим доступа: http://www.rusnauka.com/22 NIOBG_2007/Istoria/25176.doc.htm

20. Butlin John (1989-04-01). Our common future. By World commission on environment and development. (London, Oxford University Press, 1987, p. 383-595). Journal of International Development (en) 1 (2). p. $284-287$.

\section{REFERENCES}

1. Sztompka P. (1996). Sotsiologiya sotsialnykh izmeneniy [The sociology of social change]. V. A. Yadova (Eds.). Moscow: Aspekt Press [in Russian].

2. Donchenko O. (2011). Arkhetypy spilne $\mathrm{v}$ nashomu zhytti (rozpiznavannia arkhetypiv yak shliakh do unikalnosti) [Archetypes - common in our lives (recognition of archetypes as a path to uniqueness)]. Psykholohiia osobystosti - Psychology of personality, 1 (2), 170-181 [in Ukrainian].

3. Jung C. (n.d.). Psikhologiya arkhetipa rebenka [Psychology of the child archetype]. Retrieved from https:// bookap.info/book/yung_psihologiya_arhetipa_rebenka/[in Russian]. 
4. Bolshunova A. I. (2010). Osnovni kontseptsii staloho rozvytku [Basic Concepts of Sustainable Development]. Ekolohichnyi menedzhment u zahalnii systemi upravlinnia - Ecological management in the general management system: Proceedings of the Tenth Annual All-Ukrainian Scientific Conference. (Vols. 1). (p. 23-25). Sumy: SumDU [in Ukrainian].

5. Burynska O. I. (2016). Evoliutsiia kontseptsii staloho rozvytku yak holovnoi paradyhmy novoho tysiacholittia [Evolution of the concept of sustainable development as the main paradigm of the new millennium]. Naukovyi visnyk Uzhhorodskoho natsionalnoho universytetu. Seriia: Mizhnarodni ekonomichni vidnosyny ta svitove hospodarstvo - Scientific Bulletin of Uzhgorod National University. Series: International Economic Relations and World Economy, 7, 1, 57-60 [in Ukrainian].

6. Ukaz Prezydenta Ukrainy "Pro Stratehiiu staloho rozvytku "Ukraina 2020" : vid 12.01.2015, № 5/2015 [Decree of the President of Ukraine "On the Strategy of Sustainable Development "Ukraine - 2020" from 12.01.2015, № 5/2015]. (n.d.). zakon.rada.gov.ua. Retrieved from https://zakon1.rada.gov.ua/laws/ show/5/2015\#n10 [in Ukrainian].

7. Sustainable Development Goals: Ukraine. (2017). www.un.org.ua. Retrieved from http://www.un.org.ua/ images/SDGs_NationalReportEN_ Web.pdf [in English].

8. Patriotychni nastroi ukraintsi [Patriotic Sentiment for Ukrainians]. (2017). ratinggroup.ua. Retrieved from http://ratinggroup. ua/files/ratinggroup/reg_files/ rg_patriotyzm_082017.pdf [in Ukrainian].

9. Parsons T. (2000). O strukture sotsialnogo deystviya [The Structure of
Social Action]. Moscow: Akademicheskiy Proekt [in Russian].

10. Spengler O. (1998). Zakat Evropy: Ocherki morfologii mirovoy istorii. T. 1. Obraz i deystvitelnost [Der Untergang des Abendlandes. (Vols. 1). Image and reality]. Minsk [in Russian].

11. Bolshoy Entsiklopedicheskiy slovar [Big Encyclopedic Dictionary]. (n.d.). dic.academic.ru. Retrieved from https://dic.academic.ru/contents.nsf/ enc3p/ [in Russian].

12. Dohovir pro Yevropeiskyi Soiuz: vid 13.12.2007, № 994_029 [Agreement on the European Union from 13.12.2007, № 994_029]. (n.d.). zakon. rada.gov.ua. Retrieved from http://zakon.rada.gov.ua/laws/show/994_029 [in Ukrainian].

13. Stratehiia staloho rozvytku Ukrainy do 2030 roku [Strategy of steel development of Ukraine until 2030]. (2017). www.undp.org. Retrieved from https://www.undp.org/content/ dam/ukraine/docs/SDGreports / UNDP_Strategy_v06-optimized.pdf [in Ukrainian].

14. Harashchuk O. V., Kutsenko V. I. (2016). Osvitno naukova paradyhma staloho rozvytku produktyvnyk syl Ukrainy [Educational-scientific paradigm of sustainable development Producer of forces of Ukraine]. Problemy i perspektyvy ekonomiky ta upravlinnia - Problems and prospects of economy and management, 3(7), 135141 [in Ukrainian].

15. Donchenko O. A., Romanenko Yu. V. (2001). Arkhetypy sotsialnoho zhyttia i polityka: Hlybynni rehuliatyvy psykhopolitychnoho povsiakdennia [Archetypes of social life and politics: Deep regulating the psycho-political everyday life]. Kyiv: Lybid [in Ukrainian].

16. Illiashenko S. M. (2015). Pidkhody do vyboru perspektyvnykh napriamiv 
innovatsiino-oriientovanoho staloho rozvytku Ukrainy [Approaches to the selection of perspective directions of innovation-oriented sustainable development of Ukraine]. Stalyi rozvytok - XXI stolittia: upravlinnia, tekhnolohii, modeli. Dyskusii 2015 Sustainable Development $-21^{\text {th }}$ Century: Management, Technology, Model. Discussions 2015. Ye. V. Khlobystov (Eds.). (p. 33-40). Cherkasy:VydavetsChabanenkoYu.A. [in Ukrainian].

17. Khvesyk M. A. Bystriakov I. K. (2016). Innovatsiini dominanty staloho rozvytku Ukrainy [Innovative Dominances of Sustainable Development of Ukraine]. Problemy innovatsiino-investytsiinoho rozvytku. Seriia: Ekonomika ta menedzhment - Problems of Innovative-Investment Development. Series: Economics and Management, 9, 182-193. Retrieved from http://
nbuv.gov.ua/UJRN/Piir_2016_9_23 [in Ukrainian].

18. Archimandrite Georgiy (Shestun). (June 16, 2012). O zhizni i uchenii velikogo russkogo myslitelya [On the life and teachings of the great Russian thinker]. ruskline.ru. Retrieved from http://ruskline.ru/analitika/2012/06/16/nikolaj_yakovlevich_danilevskij_18221886/[in Russian].

19. Sheguta M. A. (n.d.). Slavyanskaya tsivilizatsiya: istoriya i sovremennye realii [Slavic civilization: history and modern realities]. www.rusnauka. com. Retrieved from http://www.rusnauka.com/22_NIOBG_2007/Istoria/25176.doc.htm [in Russian].

20. Butlin J. (1989). Our common future. By World commission on environment and development. Journal of International Development, 1 (2), 284-287 [in English]. 